\title{
A Blended College English Teaching Model Supported by Microlecture*
}

\author{
Jiajun Hong \\ Jiangxi Science \& Technology Normal University \\ Nanchang, China
}

\author{
Wenjuan Yan \\ Jiangxi Science \& Technology Normal University \\ Nanchang, China
}

\begin{abstract}
First of all, this paper redefines "microlecture" and emphasizes that microlecture resources should be constructed flexibly on learning problems. Based on the practice of college English teaching reform, this paper designs a blended College English teaching model with the support of microlecture, and discusses the various components of the model in detail. With microlecture resources as the main assisting learning resource, the model emphasizes the effective and flexible blending of various teaching elements and learning resources, helps students understand and solve problems in the real situation, and promotes college English teaching and promotes students' English learning.
\end{abstract}

Keywords-microlecture; college English; blended model

\section{INTRODUCTION}

Microlecture, also known as micro miniature video courses or micro class, is a product of high integration of education and information technology. It is a new educational resource which is open, sharing, flexible, short and precise and highly targeted. The concept of micro-class was first proposed by David Penrose of Juan College, New Mexico, USA in 2008, and promoted in colleges.[1]Subsequently, the teaching model centered on microlecture has emerged in the field of education, and microlecture resources websites have emerged, such as Khan Academy and TED-Ed, which are very representative microlecture resources.

In China, Hu Tiesheng from Foshan education bureau of Guangdong Province, first proposed the concept of microlecture. He believes that "microlecture is an organic combination of all kinds of teaching resources that teachers need in teaching and learning activities in the classroom according to the new curriculum standards and classroom teaching practice, taking teaching video as the main carrier."Based on the low utilization rate of educational information resources, he defined microlecture as a new type of educational resources, emphasizing the effective integration of various resources[2].Since then, with the deepening of the research and practice of microlecture, many researchers have deepened their understanding of microclasses, and they have given their own views on microlecture (Hu Tiesheng, 2011, 2012; Jiao Jianli, 2013; Li Jiahou, 2013; Yu Shengquan, 2014; Wang Zhuli, 2014).

*This research is supported by Jiangxi Social Science Fund(15wx212) and Jiangxi Science and Technology Normal University school-level teaching reform project(JGYB-16-78-78).

\section{DEFINITION AND CONNOTATION OF MiCROLECTURE IN THIS STUDY}

Since 2013, there has been an explosion of reports and researches on microlecture in China. Many national microlecture competitions have been held, and local education authorities and universities have also started microlecture construction work. With a strong microlecture competition atmosphere, most teachers are for the first time to get to know and make microlecture. Due to the fact that the concept and connotation of microlecture in China are still in a contending stage, the majority of teachers lack a clear understanding of microlecture. And the high standards of microcourses competition and the guidance of media publicity led to the elevation of microcourses, which affected the healthy and rapid development of microlecture to a certain extent [3].

As a teacher, the degree of awareness of education determines the efficiency of educational practice. Therefore, the definition and connotation of microlecture is of great significance as to guide teaching practice.

In this study, the implementation object of microlecture teaching is college students. Based on the practice of College English teaching and the research content of this subject, this study defines microlecture as a sum total of all learning activities centered around one or a series of learning problems, taking mobile learning, fragmented learning and blended learning as the main learning style, using all available resources related to the specific learning conditions (Microlecture video as the main supporting resource).

\section{The SignificAnCE OF Microlecture IN COLLEGE ENGLISH TEACHING}

\section{A. Microlecture Are More Conducive to Creating Learning} Situations and Triggering Cognitive Conflicts

Piaget's cognitive conflict theory holds that the imbalance of individual cognition helps students to construct their own knowledge system. Learning is a process of "conflict" constantly emerging, dissolving and developing [4]. In college English teaching, teachers can initiate students' cognitive conflict and create learning motivation through setting up situations. And the English microlecture resources have unique advantages in creating situations. Whether it is related to English language learning, or the knowledge of English culture and the cultivation of intercultural thinking, English 
microlecture can lead to cognitive conflicts better than other resources. In a word, the microlecture resources based on the problem design or other microlecture carefully selected or made can make teaching target oriented, so as to better help teachers to present problems, help learners find, understand and solve problems.

\section{B. Microlecture Can Improve the Efficiency of College English Learning}

According to the multimedia cognitive theory of American educational psychologist Richard Meyer[5], human information processing system has auditory channel and visual channel, and the information processed from each channel is limited. Microlecture, however, can integrate sound, video and other available resources. For example, micro-video can easily present two different knowledge representations of words and pictures, and provide subtitle support. This helps learners to ensure the effective capacity of knowledge processing and enhance the efficiency of cognitive processing. As an innovative learning resource for English language learning, English microlecture can stimulate learning interest, help students to better feel and use the language.

In addition, learning aided by microlecture in the information environment can support a variety of new learning models, such as mobile learning, fragmented learning, mixed learning, and so on, which makes it possible to make better use of teaching space and time.

\section{Microlecture Helps Teachers to Develop Creative Teaching Activities}

According to the definition and connotation of the microlecture in this study, teachers need to understand the significance of microlecture in teaching, but they do not have to adhere to the concept, form and composition of microlecture. Teachers can flexibly design or choose the appropriate resources according to the teaching problems to carry out teaching, which not only save the first-line teachers from the production of microlecture, but also greatly broaden the scope of the selection of microlecture resources. In this way, the use of teaching resources has been improved, and some repetitive labor has been eliminated. Teachers can pay more attention to creative labor in teaching, which is conducive to the improvement of teachers 'professional happiness.

\section{THE DESIGN OF THE BLENDED COLLEGE ENGLISH TEACHING MODEL SuPPORTED BY MiCROLECTURE}

\section{A. Design Principles}

1) The principle of problem-driven: The learning problem is the core of teaching activities. Teachers choose or develop microlecture resources and design learning activities around problems. It emphasizes the scientificity of problem design, the relevance of problems, the practicability, interest and enlightenment of the problems.

2) The principle of effective blending: Blended learning is adopted to match the learning style of the individual with the "right" learning technology in the "right" time, and transmit the "right" skills to the "right" people[6]. The idea of mixed learning is to find the best way to improve learning[7]. The blended learning in this study includes four dimensions of learning object, learning environment, learning style and learning evaluation[8].It emphasizes the concrete analysis of specific problems, the integration of modern learning methods such as conventional classroom learning, fragmented learning and mobile learning, and striving for the effective blending of various elements.

\section{B. Model Design}

According to the design principles mentioned above, this study designed a blended college English teaching model supported by microlecture. Combined with College English regular class teaching, it is divided into four parts: prepreparation (problem design), pre-class activity (problem exploration), in-class activity (problem solving) and afterclass activity (reflection) according to the time and space sequence of the teaching activity. 


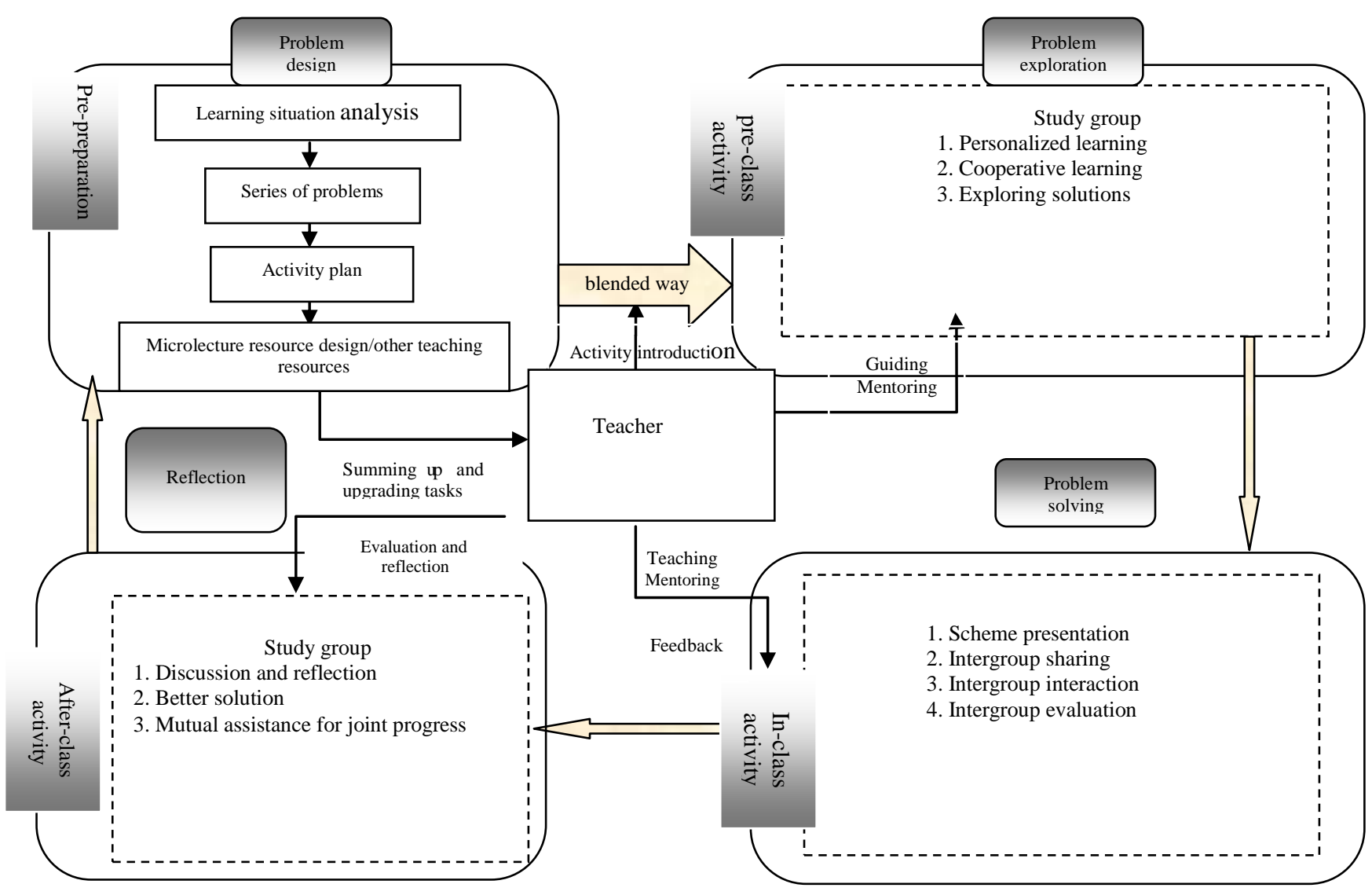

Fig. 1. The Blended College English Teaching Model Supported by Microlecture.

\section{1) Pre-preparation}

a) Form a series of problems: The preparatory work mainly includes the analysis of the situation, problem design, making teaching plan, the preparation of microlecture resources and other teaching resources. The analysis of the situation mainly includes the analysis of learners, learning content and learning environment. Among them, the analysis of learners needs to take into account factors such as the learner's learning level, learning needs, and learning devices. A series of questions are designed after a comprehensive analysis of specific teaching situations. Teachers develop teaching plans focusing around learning problems.

b) Flexible development of microlecture resources: The relevant teaching links in this model will revolve around certain learning problems, and the microlecture resources are the most important resource carriers. Therefore, it is very important to design and produce a series of microlecture resources successfully around problems and learning situations. According to the definition of microlecture in this study, the microlecture resource development can be divided into three modes: self-design mode, make-and-take mode, full dependency mode and co-construction mode. The self-design design mode means that the teacher independently designs and produces the microlecture resources according to the specific learning needs. This mode has certain requirements for the teacher's microlecture production technology, and requires more time and energy. In the make-and-take mode, teachers select suitable microlecture resources and integrate them into problem-driven teaching. This model can help teachers avoid the labor of making videos, but it requires teachers to select appropriate micro video learning resources around the teaching needs and integrate them into the teaching activities according to proper teaching design. The full dependency mode refers to the suitable ready-made microlecture resources; the co-construction mode means that teachers and students participate in the construction of microlecture resources. The above four modes need to be supplemented with relevant support and expansive teaching resources according to the specific situation.

\section{2) Teaching activity design}

a) Pre-class exploration: Teachers effectively introduce activities: teachers push microlecture resources, tasks and other resources to students through mixed channels (network channels and regular classroom channels). The problems and tasks must be clear, and the communication channels need to be diverse, smooth, and efficient. Teachers need to pay close attention to the pre-class exploration, inject learning drive as much as possible, enhance learning motivation, and guide exploration activities of students through mixed channels. 
Students explore problems before class: students explore problems in combination with the tasks assigned by teachers and relevant resources, and seek solutions to problems. Students learn and explore basing on questions and tasks with the support of microlectures. The learning situation provided by microlecture helps students understand problems better. Students develop a preliminary problem solution through personalized learning and collaborative learning.

b) Practice in class: The regular classroom is the main front of teaching. The main task is to focus on the core problems of the learning unit and promote students' mastery and internalization of knowledge. In the classroom, each learning group focuses on presenting the program and completing inter-group sharing, inter-group interaction and inter-group evaluation. First of all, each group selects representatives or groups to cooperate to present solutions, and achieve inter-group sharing, which is conducive to multidimensional discussion and mastery of core problems; other groups will ask questions and suggestions on the content, and achieve inter-group interaction, which will help break through cognitive limitations and promote deep interaction; each group evaluates the performance of other groups and achieves inter-group evaluation. The evaluation results are one of the sources of the overall evaluation results, which are conducive to the realization of inter-group competition, inter-group supervision, and mutual promotion of learning atmosphere.

Teachers can help students to further understand and solve problems by teaching, provide feedback, evaluation and guidance for students' problem solutions, help students acquire new knowledge, use the microlecture in class to provide real learning situation support, and consolidate what students have learned. Teachers can ask students to record the classroom presentations on their mobile phones and create a micro-video collection to help students intuitively feel the classroom presentation, which will help the next mutual evaluation, reflection and summary improvement.

c) Reflection after class: The teacher gives a differentiated summary and improvement task according to the overall situation of the previous stage problem solving and the different performance of each group, and combines the micro-video produced by the classroom presentation to form a new highly targeted microlecture resource. Through the students or the study group to provide a perfect problem solution as the grasp of the progress of learning, the teacher has a mixed evaluation of the whole learning process of the students, taking into consideration the presentation of the student problem solution, the evaluation of the group and the improvement of the situation.

Students carry out microlecture learning, reflect on the problem solving situation, and discuss with the members of the group, study together, present better problem solutions and achieve common progress.

\section{CONCLUSION}

With the continuous advancement of education information, the related technologies of micro-curricular development and application are becoming more and more mature, the micro-curriculum platform is increasing, and the new situation of multi-cooperation in micro-curricular resources is gradually formed. Teachers' enthusiasm for the development and application of microlecture is also increasing. However, there is currently a small number of college English microlecture, and fewer microlecture resources that can be fully integrated with teachers' daily teaching. Therefore, the development of microlecture is still difficult for teachers. The mixed learning teaching model supported by microlecture in this study not only emphasizes the ability of teachers to apply resources, but also emphasizes the ability to make flexible resources and integrate resources into teaching activities.

By constructing the blended College English teaching model supported by microlecture, teachers can flexibly develop microlecture resources suitable for individual teaching and lead the teaching more accurately. Students learn and cooperate more effectively through microlecture learning. To sum up, the blended College English learning model supported by the microlecture is a useful attempt to combine college English teaching with the information environment. While focusing on improving students' language ability, it also help students improve their ability to solve problems.

\section{REFERENCES}

[1] A Lecture in a Minute [EB/OL]. https://sjc.sanjuancollege.edu/documents/PR/Communicator/2009/Com municator-May-June-2009.pdf.

[2] $\mathrm{Hu}$ Tiesheng. "microlecture" : A New Trend in the Development of Regional Educational Information Resources [J]. Research in AudioVisual Education, 2011 (10). 胡铁生. “微课”：区域教育信息资源 发展的新趋势 [J]. 电化教育研究,2011(10).

[3] Chen Zichao, Wang Yulong, Jiang Jiafu. Problems and Countermeasures in the Current Development of Micro-Class[J]. Modern Educational Technology, 2015(10). 陈子超,王玉龙,蒋家傅.当 前微课发展面临的问题与对策 [J].现代教育技术, 2015（10）.

[4] Zhao Xuchang. The Teaching Significance of Cognitive Conflict and Its Practical Strategies[J]. Curriculum Teaching Research, 2014(10). 赵旭 昌. 认知冲突的教学意义及其实践策略[J]. 课程教学研究,2014(10).

[5] Mayer R E, Moreno R.Nine Ways to Reduce CognitiveLoad in Multimedia Learning[J] .Educational Psychologist, 2003, (38).

[6] Singh, H. \& Reed, C.:A White Paper: Achieving Success with Blended Learning[DB/OL]. http://www.leerbeleving.nl/wbts/wbt2014/blendce.pdf.

[7] Huang Ronghuai et al. Curriculum Design Theory Based on Hybrid Learning [J]. Electro-educational Research, 2009 (01). 黄荣怀等. 基于 混合式学习的课程设计理论[J].电化教育研究, 2009(01).

[8] Yin Rui, Liu Lusha. Exploration and Practice of Micro-class Application Model Based on Mixed Learning[J]. China Education Information Technology, 2015, (22). 尹 睿, 刘路莎. 以混合学习为导 向的微课应用模式探索与实践 [J]. 中国教育信息化, 2015, (22) 